\title{
Village Financial Accountability Report Assessment Presentation based on Government Accounting Principles
}

\author{
Misnawati, Gustika Sandra \\ Sekolah Tinggi Ilmu Hukum Pengayoman \\ misnawati_amir@yahoo.com, gustikasandra84@gmail.com \\ A. Cahaya, M Awaluddin A, Andi Onasis, Yusriadi Yusriadi \\ Sekolah Tinggi Ilmu Administrasi Puangrimaggalatung, Makassar, Indonesia \\ cahayaprimabone@gmail.com, awalstiaprimabone@gmail.com, andionasis2@gmail.com, \\ yusriadi.yusriadi@uqconnect.edu.au \\ Zarina Akbar \\ Universitas Negeri Jakarta, Indonesia \\ zarina_akbar@unj.ac.id
}

\begin{abstract}
Village financial management includes all activities, including planning, implementation, administration, and village financial accountability. Village finances are managed based on transparent, accountable, participatory principles and are carried out in an orderly and disciplined budget. The purpose of this study is to evaluate the presentation of the financial statements of the Padang Loang Village government, Chinese District, whether it is following the government accounting standards mandated by the Indonesian government. This study uses a descriptive qualitative research approach, where the Village Financial Accountability Report (LPJ) is the main object of the study. The informants were the Village Head, Village Secretary, Village Treasurer, and all government staffs in Padang Loang Village, Cina District, Bone Regency, South Sulawesi Province. Data sources consisted of primary data and secondary data, namely interviews and field observations, and available documents sourced from the village government office under study. Simultaneously, the research stage is carried out through data collection, data processing, data presentation, and concluding. The study results indicate that the evaluation of the production of financial accountability reports in the village of Padang Loang is quite good and following the accounting standards recommended by the government. Besides, the accountability reporting procedure carried out by the Padang Loang Village government, either the village treasurer to the Village Head or from the Village Head to the District Government (Camat) and Regency Government (Bupati), is considered fair enough, transparent, and accountable.
\end{abstract}

Keywords: Evaluation, Accountability Report, Village Finance, Government Accounting Standards, Indonesia

\section{Introduction}

The people of Indonesia are currently occupying a role as citizens who celebrate the period of change. In this age of globalization, this necessity allows the public to realize good governance to promote competition. In response to this, as outlined in Law No. 32 of 2004 on regional autonomy, the central government granted independence to the broadest possible state. This regulation aims to encourage regions to manage and regulate their households to be effective and efficient in the administration and growth of government and to enhance community services.

The amount of authority provided to local governments by the central government is the obligation of local governments to accept good governance as a means of public accountability. Three components, namely openness, engagement, and responsibility, characterize good governance. Transparency is based on the right to access information. Participation means involving the participation of the population in decision-making, either directly or indirectly, through democratic institutions that can channel their ambitions. At the same time, accountability is accountability to the public for all activities carried out (Dharmaningtyas).

The introduction of regional autonomy has conceptual implications in the context of policy and growth based on sound and responsible financial management. Regions have broad powers to control their households, but with 
Proceedings of the 11th Annual International Conference on Industrial Engineering and Operations Management Singapore, March 7-11, 2021

limited interference from the central government. It does not end at the level here but decreases to the story of the village council.

The village government's responsibility requires the capacity of village councils to be responsible for the actions carried out with development problems and the governance of villages. The obligation in question includes budgetary matters included in the Village Income and Expenditure Budget (APBDes) for the distribution of village funds being one of the elements of the APBDes (Chrystiana).

Minister of Home Affairs Regulation No 113 of 2014 specifies that village financial management covers all operations, including the planning, execution, administration, and responsibility of village finances. Village budgets are governed based on open, responsible, participatory values and are managed through an organized and disciplined account. Besides, with the implementation of Village Law No. 6 of 2014, the Government of the Village will gain significant support and must be in a position to be professionally regulated and accountable (Sululing et al.).

For this reason, village financial management, especially at the stage of village financial administration, is an important thing that must be considered by any village government. For most village chiefs and village leaders, a knowledge of accounting and financial administration in the management of village finances is required to assume responsibility for it. This report should be delivered in a standardized manner by all villagers in the region to make it easy for the Supervisory Team to assess the efficiency of development and the outcomes of development. As in Bone Regency itself, a standardized reporting format has been provided to all villages from 2015 to 2019. Every town must adopt it, even in Padang Loang Village, Cina District. Therefore, this research aims to decide the status of the reporting of the financial statements of the Government of Padang Loang Village, the Cina District, if they conform with the government accounting requirements required by the Government of Indonesia.

\section{Literature Review}

\subsection{Government Village and Village Concept}

In the world, can be found the village as a common phenomenon. A small group is bound to a certain amount of liquidity, both as a place to live (permanently) and to meet needs, mainly depending on village agriculture. The village appears to have some features in common (Rusmayanti). According to Law No. 32 of 2004, namely town, is a legal community entity with territorial borders that is empowered to administer and control the interests of the local community based on traditional roots and traditions recognized and valued by the Government of the United States of the Republic of Indonesia (Indonesia).

The local governor is the head of the village and the village authorities and representatives of the BPD. The village head is ultimately responsible for the residents of the village, whose accountability processes and procedures are passed down to the Regent or the Mayor through the District Government (Wahyuningsih et al., 2019). The new face of the village is the expectation that a new village status will follow the Village Law, role, and authority since, in the previous legislation and regulations, the village authority was just the target, and in this Village Law the village authority was mandatory (Fajri et al.).

\subsection{Village Income and Expenditure Budget (APBDes)}

The Village Income and Expenditure Budget (APBDes) is a Village Revenue and Expenditure Legislation that includes revenue sources and village expenditure allocation for one year. APB Desa consists of income from villagers, spending on villages, and funding. The draft APBDesa is debated in the village planning process. The Village Head and the Village Consultative Body (BPD) shall create the Village Budget each year under the Village Regulation (Arizona).

Village Planning and budgeting were part of the administrative framework for the independence of the village. The idea of village planning is, in effect, a subversion of Law No. 25/2004 (those who do not know about village planning subverted Law No. 17/2003) (which does not recognize APBdesa). This subversion was introduced by PP $72 / 2005$. However, the definition of village planning in Law No. improvement and improvements instead of the content of the planning in PP No. 72/2005 (Yuliansyah and Rusmianto). Previously, village planning was part of district/urban planning, but the sense of planning was more upward than neighborhood decision-making. It is a selfplanning village that sits alone and is determined separately by the town (Ariadi). 
Proceedings of the 11th Annual International Conference on Industrial Engineering and Operations Management Singapore, March 7-11, 2021

\subsection{Transparency and Accountability}

According to Regulation No 37 of 2007 of the Minister of Home Affairs of the Republic of Indonesia, Article 4 paragraph 7 of the Guidelines for Regional Financial Management, transparency is the concept of openness that enables the public to know and to have the broadest possible access to information on regional finance (Mahmudi).

Meanwhile, according to Annisa Ningrum (2010); Nuraini et al., (2019); Umanailo, (2019), responsibility is responsible for controlling capital and enforcing policies assigned to the monitoring body to accomplish the goals established periodically. Accountability is the duty to have guilt or to react or clarify the results and activities of the person/legal entity/collective leader of the association to parties who have the right or authority to request accountable information (Annisaningrum).

Transparency and transparency of municipal budgets are the responsibility of local councils in regional financial services to the public, publicly and frankly in the media. It is hoped that different stakeholders can obtain the openness and disclosure of the local authority's obligations for the reporting of financial statements under the basis that the public has the right to know this information (Hehanussa).

\subsection{Management and Presentation of Village Financial Reports}

Village financial administration is an operation to administer village finances to conform with the concept of village financial management, including the principle of openness and the direction of accountability. Administration operations cover cash refunds and disbursements of accompanying records such as general cash accounts, auxiliary tax books, and village bank books (Chrystiana).

Meanwhile, the village financial accounts' presentation is a responsibility of the village council to local councils and is the final step of the village financial management process. The Treasurer shall carry out reporting operations in a prompt, reliable, and accountable manner. The report submitted is the report on the responsibility for implementing the APBDes (Wardana).

\section{Research Method}

The study method used in this analysis is descriptive qualitative research, which is done by describing the actual properties and circumstances of the test sample (P.D). The Village Financial Responsibility Study is the focus of the analysis in this article (LPJ). In this analysis, the informants were the Village Head, Village Secretary, Village Treasurer, and all the governmental machinery of Padang Loang Village, Cina District, Bone Regency, South Sulawesi Province.

Data forms and origins consist of primary and secondary data. Preliminary data are gathered and compiled directly from interviews and field findings in the Village Government of Padang Loang, District of China, which require further processing and production for the author's interpretation. In the meantime, secondary details are processed from the Village Government Office under review, such as a short history of the administration of Padang Loang Village, the internal structure, and the filing of financial statements.

Observation, interviews, and recording have carried out data processing. In the meanwhile, the author used a descriptive approach to evaluate the results, namely the researcher who visited the research object directly, namely the Padang Loang Village Government, the Chinese District by:

a. Collecting the data by observing (observing) the results of interviews with the village records collected from the authorities in compliance with the study's purpose to be carried out.

b. Processing the data after the data is chosen according to the analysis object to be carried out after it is presented and then analyzed.

c. Presentation of data, namely by providing information to allow conclusions to be made and action taken.

d. Draw assumptions, i.e., writing relevant details gathered during the inquiry and referring to the reported wording of the issue.

\section{Result}

Village financial management is concerned with the need to support legislation and utilities. The most important thing is human capital with credible expertise and dedication, which play a crucial role in providing quality financial reporting in compliance with government accounting requirements. Government apparatus resources in Padang 
Proceedings of the 11th Annual International Conference on Industrial Engineering and Operations Management Singapore, March 7-11, 2021

Loang Village, Cina District, Bone Regency, South Sulawesi are no exception, particularly as a village treasurer who plays a crucial role in compiling and accountable village financial reports. As in Padang Loang Village, it is noted that it has an extensive revenue budget and is rising from year to year.

As regards the creation of the expenditure allocations for the village of Padang Loang Village over the last five years, beginning from 2015-2019, namely:

Table 1. Creation of the revenue budget of the Padang Loang Village, 2015 to 2019

\begin{tabular}{|l|c|c|r|r|r|}
\hline \multirow{2}{*}{ Budget } & \multicolumn{5}{c|}{ Year } \\
\cline { 2 - 6 } & $\begin{array}{c}2015 \\
\text { (IDR) }\end{array}$ & $\begin{array}{c}2016 \\
\text { (IDR) }\end{array}$ & $\begin{array}{c}2017 \\
\text { (IDR) }\end{array}$ & $\begin{array}{c}2018 \\
\text { (IDR) }\end{array}$ & $\begin{array}{r}2019 \\
\text { (IDR) }\end{array}$ \\
\hline $\begin{array}{l}\text { Regional Original Income } \\
\text { (PAD) }\end{array}$ & 5.000 .000 & 0 & 0 & 0 & 0 \\
\hline $\begin{array}{l}\text { Village Fund Allocation } \\
\text { (ADD) }\end{array}$ & 82.590 .700 & 333.681 .000 & 339.731 .900 & 308.526 .100 & 313.858 .700 \\
\hline Village Fund (DD) & 151.900 .000 & 598.045 .000 & 761.650 .000 & 907.022 .000 & 1.077 .189 .000 \\
\hline $\begin{array}{l}\text { Part of the proceeds from } \\
\text { local taxes and levies }\end{array}$ & 5.349 .000 & 14.365 .000 & 13.805 .100 & 13.820 .400 & 16.574 .600 \\
\hline Total & 244.839 .700 & 946.091 .000 & 1.115 .187 .000 & 1.229 .368 .500 & 1.407 .622 .300 \\
\hline
\end{tabular}

Source: APBDes data for Padang Loang Village, Cina District

Table 1 above indicates that Padang Loang Village's budget revenue has risen from year to year from 2015 to 2019. If this situation is uniformly spread in Indonesia, there should be no more remote and underdeveloped areas, so villagers have rights. Autonomous in the execution of the budget for the improvement and growth of the region. However, the design of buildings and facilities cannot work well without adequate and accountable reporting.

Based on interviews with the village treasurer in Padang Loang, the village's financial budget has been disbursed in many phases. As Village Fund (DD) 3 times, Village Fund Contribution (ADD) 3 times, and Revenge Tax 1 times. Both financial activities are handled closely by the Village Treasurer and include an accountability report. However, village leaders and other village workers have still been active in overseeing the operations' execution.

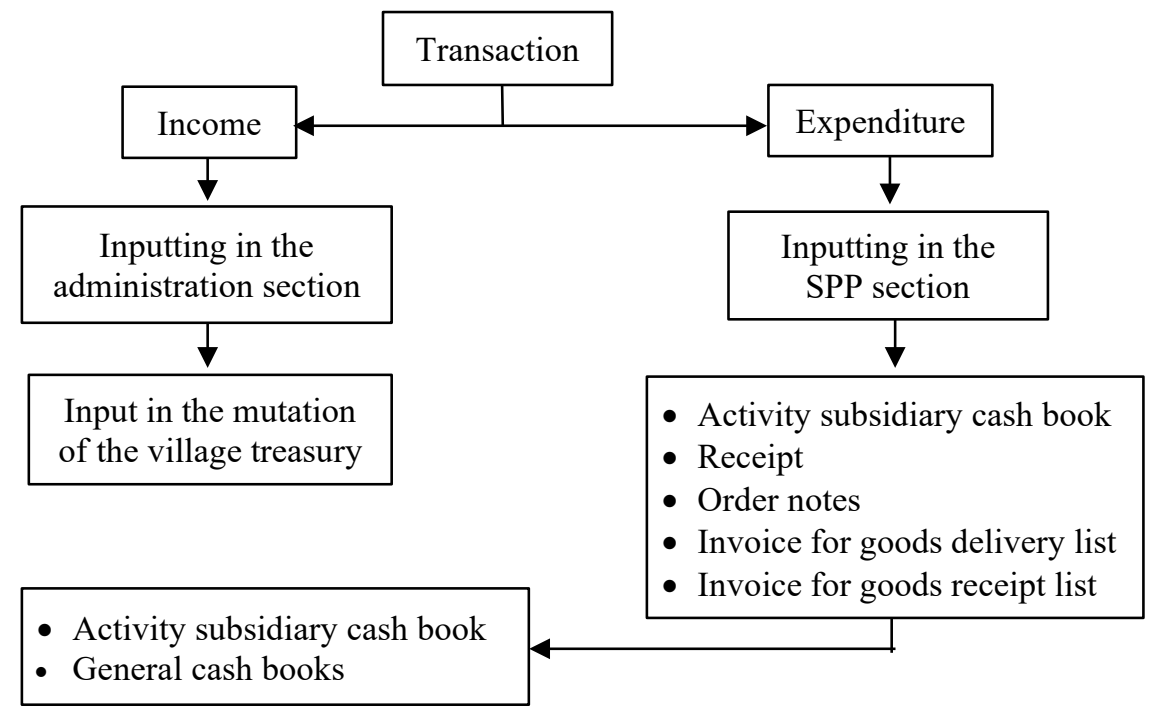

Figure 1. Flow of recording financial statement transactions

Figure 1 explained that, In the meantime, the declaration of financial income in the village of Padang Loang is carried out by first joining the administration division, which is exclusively for village tax transactions, by entering the village treasury's mutation section. In the meantime, the expenditure is rendered by inserting it in the SPP (Payment Request Letter) line. Both funds earned in the SPP provide proof of a cover letter for a declaration of 
Proceedings of the 11th Annual International Conference on Industrial Engineering and Operations Management Singapore, March 7-11, 2021

responsibility for expenditure along with supporting attachments, such as operation auxiliary cashbooks, vouchers, order notices, invoices for supplies, and a list of receipts. Also, the operation subsidiary cash book and the general cash book are included. The executioner of construction activities does not help the treasurer of the village of Padang Loang in village funds administration.

\section{Discussion}

The Village Fund supported the Village Fund Distribution, and the Other Funds earned by the Village, as well as by the Village Initial Revenue. This funding support is expected to accelerate village growth further, make the Village more autonomous, and, if necessary, enable the central Government to reduce poverty.

The village government must provide a Village Medium Term Development Plan (RPJMDes) for six years as the basis for deciding which development will become a priority in a given year. Village and Village Government authorities are deliberating on RPJMDes by including community leaders, faith leaders, women leaders, youth leaders, or other village society aspects. The engagement of community leaders is a positive preparation mechanism that will lead to good execution of the program, which will promote citizen interest in villages' growth. As Kessa said, the building must start with a good village planning phase and be followed by good program management. Efficient (rural) development is not merely the product of chance. It results from the determination of priority choices for operations, not the result of trial and error, but good preparation (Kessa).

As a result of good planning, the Village Government Work Plan (RKPD) was defined based on an annual priority scale relevant and executed in one current budget year. APBDesa is the yearly financial schedule of the Government of the Village. APBDesa covers the Village's revenue, the spending of the Village, and the Village's funding for one period or one year. This budget is the village government's responsibility to disclose the inflow and outflow of village funds organized in the village financial report.

Given the increasing amount of funds handled by the Village Government, it is considered appropriate to provide a Village Government reporting standard that can be used by the Village Government as a guide for compiling Village Financial Reports. It is a means of transparency to stakeholders such as the Central Government, the Provincial Government, the District/City Government, and other stakeholders. The village society itself.

Based on the formulation of the issue mentioned in the Introduction above, the study findings indicate that Padang Loang Village, Cina District, is in line with the Government's accounting standard format in this case, PERMENDAGRI No. 113 of 2014. In submitting an accountability report, Padang Loang Village has a form or details to be owned and completed to submit accountability. The types of data used are the APBDes Implementation Transparency Report, Village Rules, Village-Owned Asset Reports, and Government and State Government Program Reports that reach the Village. The APBDes is the Village Government's foundation to perform spending transfers in tax, expenditure, and village funding. Activities enacted in the APBDesa will enforce if the budget has been disbursed in the village treasury's account.

Like other villages, Padang Loang village is not far from raising taxes, either PPh or PPN, financial transactions. Tax levies and contributions are not made by partners but are made personally by the Village Treasurer. The village treasurer recapitulates and measures revenue and goes to the tax office to pay taxpayers' money. Taxpayers use local authority money, not from partners, even if they must pay taxes on selling goods and services in compliance with the partner laws. Yet what happened was that the government of the village was responsible for it.

Besides, all financial management has been collected in an accountability report called the APBDes. The financial statements' accountability is carried out along a systemic path, i.e., from the village government to the sub-district, which is then forwarded to the district, and the community will carry out an audit or monitoring and evaluation (monev) after the operations have been completed by $40 \%$.

The phases of the operations of the Padang Loang Village Government in the financial transparency process are as follows:

a) The Village Head shall send the Regent/Mayor a report on the responsibility for implementing the APBDesa at the end of each fiscal year.

b) Responsibility report on the implementation of the APBDesa, comprising of revenue, spending, and funding.

c) The report on the responsibility for the APBDesa Law's enforcement is provided for in the Village Regulation. 
Proceedings of the 11th Annual International Conference on Industrial Engineering and Operations Management Singapore, March 7-11, 2021

d) Village Obligation Report for the implementation of APBDesa, including 1) Format of the Accountability Report for the performance of APBDesa for the current fiscal year. 2) The Village Owned Resources Estimate as of 31 December for the current fiscal year. 3) Format of Government and Municipal Government Service Records entering the village.

e) The report on the responsibility for adopting APBDesa is an essential part of the information on the implementation of the Village Government (LPPD).

f) APBDesa Compliance Reports and Transparency Reports shall be forwarded to the Regent via Camat.

g) The village government shall send the APBDesa Implementation Transparency Report no less than 1 (one) month after the end of the current fiscal year. (interview, 04 November 2020)

In this situation, the transparency monitoring process carried out by the Government of the Padang Loang Village, either by the Village Head Treasurer or by the Government of the Village to the Camat and Regent, is good enough, as shown by the results of the observations made that the preparation of the report complies with the mandated guide. In another scenario, District Administration is often reported that the inspectorate will approve the compilation of accountability reports.

In comparison, society has never had a barrier to the growth efforts of the village council. Each form of operation shall always be followed by an Information Board containing the processes, the budget, and the fiscal year. Based on public records, the outcomes of the construction have been consistent with the specified account.

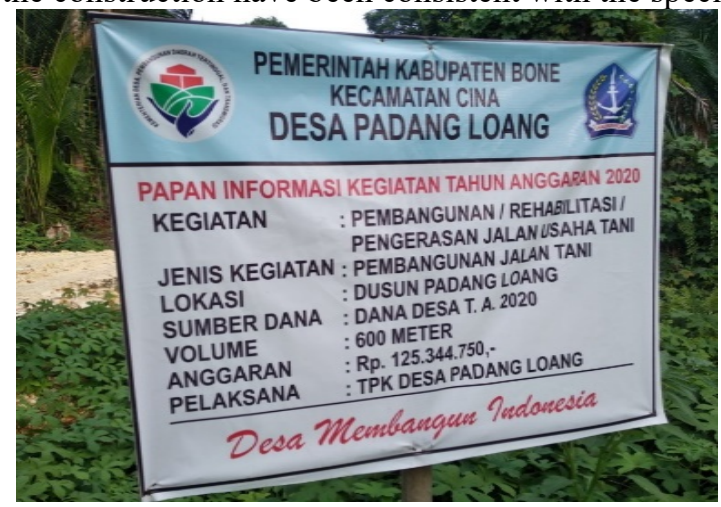

Figure 2. Example of a government development activity information board Padang Loang Village

Not just that, as a means of budget accountability, the village government of Padang Loang has created large billboards detailing all types of APBDes. It has been shown at public places in all hamlets, in front of the Village office and the two hamlets, Benteng and Cina hamlet. The village government does it to see firsthand what the village government wants to do in a year. The group is also asked to support the village government in monitoring and overseeing all operations carried out.

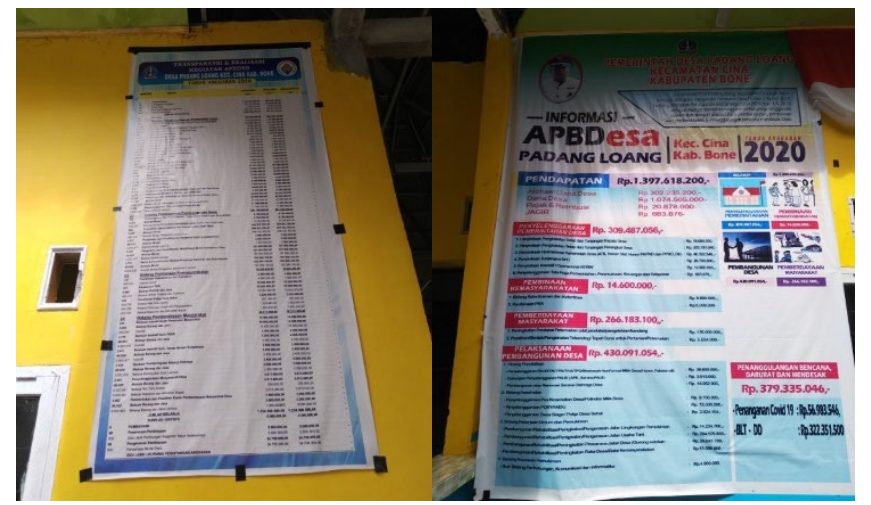

Figure 3. Example of APBDes Billboards The current budget year of the Padang Loang Village government 
Proceedings of the 11th Annual International Conference on Industrial Engineering and Operations Management Singapore, March 7-11, 2021

Therefore, as a research report related to the evaluation of the presentation of financial accountability reports in Padang Loang Village, it is quite good and following the accounting standards recommended by the government. Besides, the accountability reporting procedure carried out by the Padang Loang Village government, either the village treasurer to the Village Head or the Village Government to the Camat and Regent is considered fair enough, transparent, and accountable.

\section{Conclusion}

Based on the discussion of the above problem formulations, it is concluded that the evaluation of the presentation of financial accountability reports in Padang Loang Village is good enough and following the accounting standards recommended by the government. Besides, the accountability reporting procedure carried out by the Padang Loang Village government, either the village treasurer to the Village Head or the Village Government to the Camat and Regent is considered fair enough, transparent, and accountable.

\section{References}

Annisaningrum. “Akuntabilitas Dan Transparansi Dalam Laporan Keuangan.” Jurnal Ekonomi, 2010.

Ariadi, Andi. "Perencanaan Pembangunan Desa." Meraja Journal, 2019.

Arizona, Nanda Diaz. "Aplikasi Pengolahan Data Anggaran Pendapatan Dan Belanja Desa (APBDES) Pada Kantor Desa Bakau Kecamatan Jawai Berbasis Web.” CYBERNETICS, 2017, doi:10.29406/cbn.v1i02.745.

Chrystiana, E. T. Skripsi Pengaruh Penyajian Laporan Pertanggungjawaban Dan Aksesibilitas Terhadap Transparansi Dan Akuntabilitas Pengelolaan Alokasi Dana Desa (Add) Di Desa Wironanggan, Kecamatan Gatak, Kabupaten Sukoharjo. 2017.

Dharmaningtyas, D. Skripsi Pengaruh Kewajaran Penyajian Laporan Keuangan Terhadap Akuntabilitas Keuangan (Studi Empiris Pada Satuan Kerja Perangkat Daerah Kabupaten Temanggung). 2016.

Fajri, Rahmi, et al. "Akuntabilitas Pemerintah Desa Pada Pengelolaan Alokasi Dana Desa (Studi Pada Kantor Desa Ketindan, Kecamatan Lawang, Kabupaten Malang).” Jurnal Administrasi Publik (JAP), 2015.

Hehanussa, S. "Pengaruh Penyajian Laporan Keuangan Daerah Dan Aksesibilitas Laporan Keuangan Daerah Terhadap Transparansi Dan Akuntabilitas Pengelolaan Keuangan Daerah Kota Ambon." Jurnal UNISSULA., 2015.

Indonesia, Republik. UU No. 32 Tahun 2004 Tentang Otonomi Daerah. 32, 2004.

Kessa, W. Perencanaan Dan Pelaksanaan Pembangunan Desa. Kementerian Desa, Pembangunan Daerah Tetinggal, dan Transmigrasi Republik Indonesia, 2015.

Mahmudi. Manajemen Keuangan. Airlangga, 2010.

Nuraini, N., Riadi, A., Umanailo, M. C. B., Rusdi, M., Badu, T. K., Suryani, S., ... Hentihu, V. R. (2019). Political Policy for the development of Education. International Journal of Scientific \& Technology Research, 8(10).

P.D, Sugiono. "Metode Penelitian Pendidikan Pendekatan Kuantitatif.Pdf." Metode Penelitian Pendidikan Pendekatan Kuantitatif, Kualitatif Dan R\&D, 2014.

Rusmayanti, A. "Sistem Informasi Pengelolaan Keuangan Pada Desa Ngadirejan." Journal Speed-Sentra Penelitian Engineering Dan Edukasi, 2014, pp. 35-39.

Sululing, S., et al. "Analisis Laporan Keuangan Desa." Conference on Innovation and Application of Science and Technology (CIASTECH 2018), Universitas Widyagama Malang, 2018.

Umanailo, M. C. B. (2019). Structure of Social Change in Industrial Society. Proceedings of the International Conference on Industrial Engineering and Operations Management Riyadh, 668-672. Riyadh, Saudi Arabia: IEOM Society International.

Wardana, Ibnu. "Akuntabilitas Dalam Pengelolaan Keuangan Desa (Studi Pada Pemerintah Desa Di Kabupaten Magelang)." Jurnal Akuntansi, 2016.

Yuliansyah, and Rusmianto. “Akuntansi Desa.” Jakarta: Salemba Empat, 2015.

\section{Biography}

Misnawati is a lecturer in the Department of Law at the Watampone College of Law, Makassar, Indonesia. He earned a master's degree through scholarship assistance from the Ministry of Youth and Sports of the Republic of Indonesia. In addition to being a lecturer, he is also a social worker who assists the poor in empowering themselves to get out of the poverty line. He has published a book about his profession as a social worker. Besides that, he has also published many international and national journals through collaboration with several other lecturers who focus on multidisciplinary science. 
Proceedings of the 11th Annual International Conference on Industrial Engineering and Operations Management Singapore, March 7-11, 2021

Gustika Sandra is a lecturer at Law Studies Department of Sekolah Tinggi Ilmu Hukum Pengayoman, Indonesia. Her areas of interest and research include social science and legal studies.

A. Cahaya is a lecture and chancellor at Social Science Department of Sekolah Tinggi Ilmu Administrasi Puangrimaggalatung, Indonesia. Her areas of interest and research include social science, political science, sociology, and public administration. She has published some books, articles in national and international journals.

A Awaluddin $\mathbf{M}$ is a lecture at Social Science Department of Sekolah Tinggi Ilmu Administrasi Puangrimaggalatung, Indonesia. His areas of interest and research include social science, political science, sociology, and public administration. He has published some books, articles in national and international journals.

Andi Onasis is is a lecture at Social Science Department of Sekolah Tinggi Ilmu Administrasi Puangrimaggalatung, Indonesia. His areas of interest and research include social science, political science, sociology, and public administration. He has published some articles in national journals.

Yusriadi Yusriadi is a lecturer at Public Administration Department of Sekolah Tinggi Ilmu Administrasi Puangrimaggalatung, Indonesia and chancellor on Sekolah Tinggi Ilmu Hukum Pengayoman. His areas of interest and research include social science, political science, sociology, legal studies, and public administration. He has published some books and many articles in national and international journals. He is a reviewer and editor in some local and international journals.

Zarina Akbar is a lecturer at Psychology Department of Universitas Negeri Jakarta, Indonesia. Her areas of interest and research include growth, positive clinical psychology, neuroeducation, and cross-cultural psychology. She has published some books and many articles in national and international journals. 